\title{
Nitric Oxide Regulates the Calcium Current in Isolated Human Atrial Myocytes
}

\author{
Michael Kirstein, ${ }^{\ddagger}$ Michèle Rivet-Bastide, ${ }^{\ddagger}$ Stéphane Hatem, ${ }^{\$}$ Agnès Bénardeau, ${ }^{\$}$ Jean-Jacques Mercadier, ${ }^{\$}$ \\ and Rodolphe Fischmeister ${ }^{\ddagger}$ \\ ${ }^{\ddagger}$ Laboratoire de Cardiologie Cellulaire et Moléculaire, Institut National de la Santé et de la Recherche Médicale CJF 92-11, Université \\ de Paris-Sud, Faculté de Pharmacie, F-92296 Châtenay-Malabry, France; and ${ }^{\S}$ Laboratoire de Cardiologie Moléculaire et Cellulaire, \\ Centre National de la Recherche Scientifique URA 1159, Université de Paris-Sud, Hôpital Marie-Lannelongue, F-92350 Le Plessis \\ Robinson, France
}

\begin{abstract}
Cardiac $\mathrm{Ca}^{2+}$ current $\left(\mathrm{I}_{\mathrm{Ca}}\right)$ was shown to be regulated by cGMP in a number of different species. Recently, we found that the NO-donor SIN-1 (3-morpholino-sydnonimine) exerts a dual regulation of $I_{C a}$ in frog ventricular myocytes via an accumulation of cGMP. To examine whether NO also regulates $\mathrm{Ca}^{2+}$ channels in human heart, we investigated the effects of SIN-1 on $I_{C a}$ in isolated human atrial myocytes. An extracellular application of SIN-1 produced a profound stimulatory effect on basal $I_{C a}$ at concentrations $>1$ pM. Indeed, 10 pM SIN-1 induced $\mathrm{a} \approx 35 \%$ increase in $\mathrm{I}_{\mathrm{Ca}}$. The stimulatory effect of SIN-1 was maximal at $1 \mathrm{nM}(\approx 2$-fold increase in $I_{C_{a}}$ ) and was comparable with the effect of a saturating concentration ( $1 \mu M$ ) of isoprenaline, a $\beta$-adrenergic agonist. Increasing the concentration of SIN-1 to $1-$ $100 \mu \mathrm{M}$ reduced the stimulatory effect in two thirds of the cells. The stimulatory effect of SIN-1 was not mimicked by SIN-1C, the cleavage product of SIN-1 produced after liberation of NO. This suggests that NO mediates the effects of SIN-1 on $I_{\mathrm{Ca}}$. Because, in frog heart, the stimulatory effect of SIN-1 on $I_{\mathrm{Ca}}$ was found to be due to cGMP-induced inhibition of cGMP-inhibited phosphodiesterase (cGI-PDE), we compared the effects of SIN-1 and milrinone, a cGI-PDE selective inhibitor, on $I_{C a}$ in human. Milrinone (10 $\left.\mu M\right)$ induced a strong stimulation of $I_{C a}(\approx 150 \%)$, demonstrating that cGI-PDE controls the amplitude of basal $\mathrm{I}_{\mathrm{Ca}}$ in this tissue. In the presence of milrinone, SIN-1 (0.1-1 nM) had no stimulatory effect on $I_{C a}$, suggesting that the effects of SIN-1 and MIL were not additive. We conclude that NO may stimulate $I_{C a}$ in human atrial myocytes via inhibition
\end{abstract}

This paper was presented in abstract form at the Physiological Society Meeting in Liverpool, United Kingdom on 11-13 April 1994.

Address correspondence to Dr. Rodolphe Fischmeister, INSERM CJF92-11, Faculté de Pharmacie, F-92296 Châtenay-Malabry Cedex, France. Phone: 46-83-57-71; FAX: 46-83-54-75; e mail: Fisch@sinaps.vjf.inserm.fr.

Received for publication 11 August 1994.

1. Abbreviations used in this paper: cGI-PDE, cGMP-inhibited PDE; cGMP-PK, cGMP-dependent protein kinase; cGS-PDE, cGMP-stimulated PDE; $\mathrm{I}_{\mathrm{Ca}}$, L-type calcium current; PDE, phosphodiesterase; SIN1, 3-morpholino-sydnonymine; SIN-1C, $N$-morpholino-imino-acetonitril; SNP, sodium nitroprusside.

J. Clin. Invest.

(C) The American Society for Clinical Investigation, Inc. 0021-9738/95/02/0794/09 \$2.00

Volume 95, February 1995, 794-802 of the cGI-PDE. (J. Clin. Invest. 1995. 95:794-802.) Key words: human cardiac myocytes - calcium channel current - nitric oxide • cGMP • cGMP-inhibited phosphodiesterase

\section{Introduction}

Regulation of the cardiac calcium channel current $\left(\mathrm{I}_{\mathrm{Ca}}\right)^{1}$ is often correlated with the regulation of cardiac contraction. For example, the stimulatory effect of cAMP on $\mathrm{I}_{\mathrm{Ca}}$ accounts for most of the positive inotropic effect of noradrenaline and $\beta$-adrenergic agonists $(1,2)$. The mechanism by which cAMP stimulates $I_{\mathrm{Ca}}$ has been well documented. cAMP activation of cAMP-dependent protein kinase leads to phosphorylation of L-type $\mathrm{Ca}^{2+}$ channels (or a closely associated protein), resulting in an increase in the mean probability of channel opening and stimulation of macroscopic $\mathrm{I}_{\mathrm{Ca}}(1-3)$. There is ample evidence that cGMP exerts opposite contractile and electrical responses in the heart to those elicited by cAMP $(1,4-13)$. Therefore it was conceivable that both nucleotides exert opposite actions on $\mathrm{I}_{\mathrm{Ca}}$. Among the evidence supporting this hypothesis are the findings that cGMP reduces ${ }^{45} \mathrm{Ca}$ flux across the sarcolemma (6), shortens action potential duration (14), and inhibits $\mathrm{Ca}^{2+}$-dependent action potentials $(15-18)$. Although in initial voltage-clamp studies on multicellular cardiac preparations no effect of a photoactivatable cGMP analogue on $\mathrm{I}_{\mathrm{Ca}}$ was found $(19,20)$, experiments on isolated cells from frog $(21,22)$, guinea-pig $(23,24)$, rat (25), and embryonic chicken (26-28) ventricular tissue have provided ample support for an inhibition of $\mathrm{I}_{\mathrm{Ca}}$ by cGMP. Similarly, cGMP has been shown to modulate $\mathrm{I}_{\mathrm{Ca}}$ in fetal human ventricular myocytes (28). Combining patch-clamp techniques with intracellular perfusion technique (21) has allowed the examination of the effects of the internal application of cAMP cGMP, and their hydrolysis-resistant analogues, as well as those of cGMP-dependent protein kinase (cGMP-PK) in isolated cardiac myocytes. Such experiments have helped in elucidating the molecular mechanisms involved in cGMP regulation of $\mathrm{I}_{\mathrm{Ca}}$

Three pathways for cGMP action have been demonstrated: (a) activation of an endogenous cGMP-PK, which leads to the inhibition of $\mathrm{I}_{\mathrm{Ca}}$ in guinea pig $(23,24)$, rat $(25,29)$, and chicken (26-28) ventricular cells but stimulates $\mathrm{I}_{\mathrm{Ca}}$ in rabbit ventricular cells (30); ( $b$ ) activation of the cGMP-stimulated phosphodiesterase (cGS-PDE), which, in frog ventricular myocytes, accounts for the inhibition of CAMP- and isoprenaline-stimulated $\mathrm{I}_{\mathrm{Ca}}$ observed upon dialysis with cGMP $(21,22,29)$; and (c) blockade of the cGMP-inhibited phosphodiesterase (cGI-PDE), reported in mammalian and batracian heart cells $(31,32)$, which results in an increase of $\mathrm{I}_{\mathrm{Ca}}$ in mammalian heart cells when the concentration of intracellular cAMP is not saturating (24). These observations suggested a role of cGMP as a second mes- 
senger in cardiac contractility that would involve guanylyl cyclase activation.

The heart releases NO (33) and NO enhances soluble guanylyl cyclase activity in the heart (34). Therefore it was conceivable that NO might modulate cardiac calcium channel activity. One easy way to examine the effect of NO on a cardiac myocyte is to expose the myocyte to NO-donors. These compounds release NO in a metabolic dependent [glycerol trinitrate, sodium nitroprusside (SNP)] and/or independent manner (SIN1; SNP) (35). Accordingly, NO-donors increase cGMP levels in isolated cardiomyocytes (36). In frog (37) and guinea pig ventricular cells (38), NO-donors appear to regulate $\mathrm{I}_{\mathrm{Ca}}$ in a manner consistent with an elevation of intracellular cGMP. First, like cGMP, SIN-1 or SNP (up to millimolar concentrations) were found to be ineffective in altering the kinetics or the amplitude of basal $I_{C a}(37,38)$. Second, after $I_{C a}$ had been elevated by either isoprenaline, forskolin, or intracellular cAMP, SIN-1 and SNP exerted profound inhibitory effects. This inhibitory effect, seen in the micromolar range of concentration, was attributed to cGMP-induced activation of cGS-PDE in the frog (37) and to cGMP activation of cGMP-PK in the guinea pig (38) according to the different mechanisms of action of cGMP observed in these two cardiac preparations (29). In addition to its inhibitory effect, SIN-1 also produces a stimulatory effect on $\mathrm{I}_{\mathrm{Ca}}$. In frog cells, this effect was most prominent when SIN-1 was used in the nanomolar range of concentrations and occurred only when $\mathrm{I}_{\mathrm{C}}$ had been previously increased by cAMP-dependent phosphorylation (38).

Little is known on the regulation of $\mathrm{Ca}^{2+}$ channel current in human heart by cGMP and/or NO. In a single study, it was reported (as data not shown) that an extracellular application of 8-bromo-cGMP (100 $\mu \mathrm{M})$, a hydrolysis-resistant and lipophylic analogue of cGMP, decreased basal $\mathrm{I}_{\mathrm{Ca}}$ amplitude in human fetal ventricular cells (28). In the same preparation, the atrial natriuretic peptide atriopeptin III, which activates the particulate guanylyl cyclase and induces an increase in cGMP concentration in isolated cardiac myocytes (36), was found to reduce basal $\mathrm{I}_{\mathrm{Ca}}(28)$. However, in adult human atrial cells, this compound appeared to increase basal $I_{C a}$ (39). To our knowledge, there has been no report on the regulation of $\mathrm{I}_{\mathrm{Ca}}$ in adult human cardiac myocytes by either cGMP or NO. To get some insights into the cellular mechanisms of action of cGMP and NO on human cardiac muscle, we have examined in the present study the effects of the NO-donor $\mathrm{SIN}-1$ on $\mathrm{I}_{\mathrm{Ca}}$ in isolated human atrial myocytes. Like in frog, we found that nanomolar concentrations of SIN-1 produced a stimulatory effect on $I_{C a}$. However, unlike in frog, this effect appeared on basal $I_{C a}$, i.e., in the absence of a previous stimulation of the current by cAMP-elevating agents.

\section{Methods}

Surgery. All protocols for obtaining human cardiac tissue were approved by the ethics committee of our institution (GREBB, Hôpital de Bicêtre, Université de Paris-Sud). Human right atrial appendages were obtained from 31 patients (aged 16-81 yr) undergoing surgery for congenital, ischemic, or valvular heart diseases (Table I) in the Hôpital MarieLannelongue, Le-Plessis-Robinson, France. Most patients received a pharmacological pretreatment (Ca-channel blockers, $\beta$-adrenergic antagonists, diuretics, ACE inhibitors, digitalis, NO-donors, and/or antiarrhythmic drugs) that was stopped $24 \mathrm{~h}$ before surgery. In addition to the medications listed, all patients received sedatives, anesthesia, and antibiotics (Table I). Dissociation of the cells was realized immediately after surgery.

Cell dissociation. The isolation of single myocytes from human atria samples was performed as described earlier (40) with minor modifications. After the excision of the atrial tissue, the tissue was washed for $3 \mathrm{~min}$ in an oxygenated $\left(95 \% \mathrm{O}_{2}, 5 \% \mathrm{CO}_{2}\right)$ calcium free Tyrode solution composed of (mM) $136 \mathrm{NaCl}, 5.4 \mathrm{KCl}, 1.1 \mathrm{MgCl}_{2}, 10$ Hepes, 20 taurine, 5 sodium-pyruvate, 10 D-glucose, $0.3 \mathrm{NaH}_{2} \mathrm{PO}_{4}$, adjusted to a $\mathrm{pH}$ of 7.3 with $\mathrm{NaOH}$. Then, the tissue was cut into small pieces of $\sim 1$ $\mathrm{mm}^{3}$ and $30 \mathrm{mM}$ 2,3-butanedionemonoxine was added to the solution to inhibit cellular metabolism. Afterward, a 30-min digestion with collagenase $(200 \mathrm{U} / \mathrm{ml})$ and protease $(4 \mathrm{U} / \mathrm{ml})$ in $10 \mathrm{ml}$ of nominally calcium free BSA $(5 \mathrm{mg} / \mathrm{ml})$ containing Tyrode solution was performed at $37^{\circ} \mathrm{C}$. The solution was then replaced by $5 \mathrm{ml}$ of fresh solution that contained no protease but $400 \mathrm{U} / \mathrm{ml}$ collagenase. Every $5 \mathrm{~min}$, a small sample was examined under a microscope to follow up the process of cell dissociation. After adequate dissociation (which lasted $\sim 30 \mathrm{~min}$ ) the tissue was passed through a mesh of $250 \mu \mathrm{m}$ pore size. The cells were then settled down, centrifuged at $400 \mathrm{rpm}$ for $1 \mathrm{~min}$, and the pellet was resuspended in an enzyme free KB solution (41), which contained (mM) 70 potassium glutamate, $25 \mathrm{KCl}, 20 \mathrm{D}$-glucose, 10 taurine, 10 Hepes, 0.5 EGTA, pH 7.3 with $\mathrm{NaOH}$. The cells were then placed in a Petri dish on the stage of an inverted microscope for subsequent patchclamp experiments.

Electrophysiological experiments. The whole-cell configuration of the patch-clamp technique was used to record the high-threshold calcium current $\left(\mathrm{I}_{\mathrm{Ca}_{\mathrm{a}}}\right)$ on $\mathrm{Ca}^{2+}$-tolerant cells, which had kept their characteristics, rod-shape, and striations. In the routine protocols, the cells were depolarized every $8 \mathrm{~s}$ from $-80 \mathrm{mV}$ holding potential to $0 \mathrm{mV}$ for 200 or 400 $\mathrm{ms}$ after a short prepulse $(50 \mathrm{~ms})$ to $-50 \mathrm{mV}$. This prepulse together with tetrodotoxin $(30 \mu \mathrm{M})$ was used to eliminate fast sodium currents. $\mathrm{K}^{+}$currents were blocked by replacing all $\mathrm{K}^{+}$ions with intracellular and extracellular $\mathrm{Cs}^{+}(42)$. For the determination of current-voltage relationships for $\mathrm{I}_{\mathrm{Ca}}$ (see Fig. 5, $A$ and $C$ ) and $\mathrm{I}_{\mathrm{Ca}}$ inactivation curve (see Fig. 5, $B$ and $D$ ), a double pulse voltage-clamp protocol was used that was derived from that used in frog cardiomyocytes $(42,43)$. Briefly, every $4 \mathrm{~s}$, the membrane potential of the cell, which was normally maintained at its holding value of $-80 \mathrm{mV}$, experienced the following sequence of events: $-50 \mathrm{mV}$ for $10 \mathrm{~ms}$, different potentials values ranging from -100 to $+100 \mathrm{mV}$ for $200 \mathrm{~ms},-50 \mathrm{mV}$ for $3 \mathrm{~ms}$, and 0 $\mathrm{mV}$ for $200 \mathrm{~ms}$ (see inset in Fig. 5B). Voltage-clamp protocols were generated by a challenger/09-VM programmable function generator (Kinetic Software, Atlanta, GA). The cells were voltage-clamped using a patch-clamp amplifier (model RK-400; Biologic, Claix, France). Currents were sampled at a frequency of $10 \mathrm{kHz}$ using a 12-bit analog-todigital converter (DT2827; Data Translation, Marlboro, MA) connected to a PC compatible computer (386/33 System-pro, Compaq, Houston, $\mathrm{TX})$. All experiments were done at room temperature $\left(19-25^{\circ} \mathrm{C}\right)$.

Solutions. Control external solution consisted of $(\mathrm{mM}) 107.1 \mathrm{NaCl}$, 10 Hepes, $40 \mathrm{CsCl}, 4 \mathrm{NaHCO}_{3}, 0.8 \mathrm{NaH}_{2} \mathrm{PO}_{4}, 1.8 \mathrm{MgCl}_{2}, 1.8 \mathrm{CaCl}_{2}$, 5 D-glucose, 5 sodium pyruvate, $\mathrm{pH} 7.4$ adjusted with $\mathrm{NaOH}$. Tetrodotoxin $(30 \mu \mathrm{M})$ was added directly in the perfused solution when a measurement was done. Control or drug-containing solutions were applied to the exterior of the cell using a perfusion system (RSC-100, Biologic). The cell was positioned at the opening of $250-\mu \mathrm{m}$ inner diameter capillary tubings flowing at a rate of $\approx 10 \mu \mathrm{l} / \mathrm{min}$. Patchelectrodes $(0.8-1.5 \mathrm{M} \Omega)$ were filled with control internal solution that consisted of (mM) $119.8 \mathrm{CsCl}, 5$ EGTA (acid form), $4 \mathrm{MgCl}_{2}, 5$ creatine phosphate disodium salt, $3.1 \mathrm{Na}_{2}$-ATP, $0.42 \mathrm{Na}_{2}$-GTP, 10 Hepes, $62 \mu \mathrm{M} \mathrm{CaCl}_{2}$ (pCa 8.5), pH 7.2 adjusted with $\mathrm{CsOH}$.

Materials. Sodium salt nucleotides, trypsin, collagenase (type V), and protease (type XXIV) were obtained from Sigma (L'Isle d'Abeau Chesnes, France). Milrinone was a generous gift from Starling-Winthrop (Rensselaer, New York). SIN-1 (3-morpholino-sydnonymine) and SIN-1C ( $N$-morpholino-imino-acetonitril) were generous gifts from Dr. J. Winicki (Hoechst Laboratories, France). Tetrodotoxin was from 
Latoxan (Rosans, France) and all other drugs were from Sigma. During the preparation of solutions, SIN-1 was protected from UV irradiation of natural light. It was solubilized in standard external solution $<15$ min before being applied onto the cell under investigation, i.e., only fresh NO-donors-containing solutions were tested. SIN-1C was used in the same conditions as SIN-1.

Data analysis. The maximal amplitude of whole-cell $\mathrm{I}_{\mathrm{Ca}}$ was measured as the difference between the peak inward current and the leak current $\left(I_{400}\right.$ or $\left.I_{200}\right)$, which was the current amplitude at the end of the 400- or 200-ms duration pulse, respectively (42). Currents were not compensated for capacitive and leak currents. Cell membrane capacitance and series resistance were measured by exponential analysis of current responses to $1-\mathrm{mV}$ step changes in membrane potential. Membrane capacitance was $100.4 \pm 11$ (mean \pm SEM) pF and series resistance was $5.7 \pm 0.6 \mathrm{M} \Omega(n=60)$. The on-line analysis of the recordings was made possible by programming a PC compatible computer in Pascal language to determine, for each membrane depolarization, peak and steady-state current values (42).

The results are expressed as mean \pm SEM. Statistical analysis was performed with the computer program Statgraph (STSC Inc., Rockville, MD). Differences between means were tested for statistical significance by Student's $t$ test. In the text, the "basal" condition refers to the absence of either isoprenaline or milrinone.

\section{Results}

$\mathrm{I}_{\mathrm{Ca}}$ was recorded in human atrial myocytes using the wholecell configuration of the patch-clamp technique (44). Basal $\mathrm{I}_{\mathrm{Ca}}$ amplitude was measured 3-15 min after patch break to allow for equilibration between intracellular and pipette solutions. Basal $\mathrm{I}_{\mathrm{Ca}}$ amplitude at $0 \mathrm{mV}$ membrane potential was on average $228 \pm 22 \mathrm{pA}$ and $\mathrm{I}_{\mathrm{Ca}}$ density, which represents the ratio of $\mathrm{I}_{\mathrm{Ca}}$ amplitude to membrane capacitance, and was $2.8 \pm 0.3 \mathrm{pA} / \mathrm{pF}$ $(n=60)$. Average values of basal $\mathrm{I}_{\mathrm{Ca}}$ density are given in Table I for each patient. As shown, there was a large scatter in the densities of $\mathrm{I}_{\mathrm{Ca}}$. Differences in $\mathrm{I}_{\mathrm{Ca}}$ densities were found not only between different patients but also between individual cells from the same patient with no obvious correlation with the diagnosis, sex, age, or pretreatment of the patients. Fig. 1 shows an experiment in which three different concentrations of SIN$1(10 \mathrm{nM}, 1 \mu \mathrm{M}$, and $100 \mu \mathrm{M})$ were tested on a human atrial myocyte. SIN-1 was applied extracellularly and $\mathrm{I}_{\mathrm{Ca}}$ amplitude was measured at $0 \mathrm{mV}$ membrane potential. As shown, $10 \mathrm{nM}$ SIN-1 produced a strong stimulation of basal $\mathrm{I}_{\mathrm{Ca}}$. However, when the concentration of SIN-1 was increased to 1 and 100 $\mu \mathrm{M}$, the stimulatory effect was reduced. To test whether this was due to some rundown of $\mathrm{I}_{\mathrm{Ca}}$ or to some desensitization or toxic effects of SIN-1 when used at these high concentrations, the myocyte was challenged again with a $10-\mathrm{nM}$ concentration of SIN-1 after complete washout of the highest concentration $(100 \mu \mathrm{M})$ used. Washout of SIN-1 reduced $\mathrm{I}_{\mathrm{Ca}}$ back to its basal amplitude, demonstrating that the effects of SIN-1 were fully reversible (Fig. 1). Applying $10 \mathrm{nM} \mathrm{SIN-1} \mathrm{for} \mathrm{the} \mathrm{second} \mathrm{time}$ induced a second increase in $\mathrm{I}_{\mathrm{Ca}}$. Although the second effect was smaller than the one seen at the first application, it was larger than the effect seen earlier with $100 \mu \mathrm{M}$ SIN-1. This suggests that the reduced stimulatory effect of SIN-1 observed at 1 and $100 \mu \mathrm{M}$ was not due to rundown of $\mathrm{I}_{\mathrm{Ca}}$ or to a desensitization process. The experiment of Fig. 1 is representative of 10 out of a total of 15 experiments in which successively increasing concentrations of SIN-1 were tested on the same cell. In these 10 experiments, micromolar concentrations of SIN-1 counteracted the stimulatory effect of nanomolar concentrations, sug- gesting the presence of an inhibitory effect in the high range of concentrations. In the remaining five experiments, however, increasing the concentration of SIN-1 above $10 \mathrm{nM}$ did not reduce the stimulatory effect of SIN-1 on $\mathrm{I}_{\mathrm{Ca}}$. At this stage, the variability between cells could not be easily related to any of the characteristics of the patients as listed in Table I. In the following, we mainly focused our attention to the stimulatory effect of SIN-1, which was more consistently found.

The stimulatory effect of SIN-1 on $\mathrm{I}_{\mathrm{Ca}}$ was dose dependent. Fig. $2 A$ shows an experiment in which three increasing concentrations of SIN-1 (100 pM, $1 \mathrm{nM}$, and $10 \mathrm{nM})$ were tested on the same human atrial myocyte. A 100-pM concentration of SIN-1 produced an $\approx 45 \%$ increase in basal $\mathrm{I}_{\mathrm{Ca}}$. Increasing the concentration to $1 \mathrm{nM}$ enhanced the current further. However, an application of $10 \mathrm{nM} \mathrm{SIN-1} \mathrm{did} \mathrm{not} \mathrm{produce} \mathrm{any} \mathrm{further}$ increase in $\mathrm{I}_{\mathrm{Ca}}$, suggesting that the maximal stimulatory effect was attained at $1 \mathrm{nM}$. The results of a number of similar experiments are summarized in the dose-response curve of Fig. $2 B$. Although a large variability in the degree of response was observed among different cells, as low as 10 pM SIN-1 already produced a significant increase in $\mathrm{I}_{\mathrm{Ca}}$. The maximal effect was observed with $1 \mathrm{nM} \mathrm{SIN-1.} \mathrm{The} \mathrm{large} \mathrm{scatter} \mathrm{in} \mathrm{the} \mathrm{data} \mathrm{obtained}$ at $10 \mathrm{nM} \mathrm{SIN-1}$ and the reduced mean stimulatory effect could result from a superimposed inhibitory effect of SIN-1 already present in some of these cells at this concentration.

The spontaneous liberation of NO from SIN-1 is accompanied by the release of SIN-1C, the other cleavage product of SIN-1 (45). Therefore we examined whether the effect of SIN1 could be due to SIN-1C liberation. We found that, like in frog ventricular cells (37), $0.1 \mathrm{nM}$ to $1 \mu \mathrm{M}$ SIN-1C exerted no significant effect on $\mathrm{I}_{\mathrm{Ca}}$ (data not shown). Thus it is most likely that the stimulatory effect of SIN-1 on $\mathrm{I}_{\mathrm{Ca}}$ in human atrial myocytes is due to NO liberation.

So far, our results demonstrate that SIN-1 produces a stimulatory effect on $\mathrm{I}_{\mathrm{Ca}}$ in human atrial myocytes. This was also an observation made in frog ventricular myocytes (37). Because in frog we found that the stimulatory effect of SIN-1 on $I_{C a}$ was due to an elevation in cAMP concentration after cGMP inhibition of cGI-PDE, we compared the stimulatory effect of SIN-1 with the effects of agents known to increase cAMP levels in human cardiac myocytes. First, we used isoprenaline, a $\beta$ adrenergic agonist, which stimulates cAMP synthesis via the activation of adenylyl cyclase. As already shown in this preparation $(46,47)$, isoprenaline produced a strong increase in $I_{C a}$. At $100 \mathrm{nM}$ or $1 \mu \mathrm{M}$ concentrations, the stimulatory effect of isoprenaline was comparable with that produced by $1 \mathrm{nM} \mathrm{SIN-}$ 1 (Fig. 3). Second, we used milrinone, an inhibitor of cGIPDE (48). $10 \mu \mathrm{M}$ milrinone also produced a strong stimulation of $\mathrm{I}_{\mathrm{Ca}}$ that was comparable with the maximal effects of isoprenaline and SIN-1 (Fig. 3). This latter result is at variance with what was found in frog myocytes in which milrinone has no effect on $I_{C a}$ under basal conditions $(31,32)$. It suggests that, unlike in the frog myocyte, the basal amplitude of $\mathrm{I}_{\mathrm{Ca}}$ in human atrial cell is the result of significant basal activities of adenylyl cyclase and/or cAMP-dependent protein kinase.

To investigate the mechanism(s) responsible for the stimulatory effect of SIN-1 on $\mathrm{I}_{\mathrm{Ca}}$ in human atrial cells, we tested the effects of SIN-1 in the presence and absence of milrinone. Fig. $4 A$ shows an experiment in which SIN-1 ( $100 \mathrm{pM})$ was applied to a cell either alone or on top of an application of milrinone $(10 \mu \mathrm{M})$. As shown, $100 \mathrm{pM}$ SIN-1 produced a stimulation of 


\begin{tabular}{|c|c|c|c|c|}
\hline Patient & Age/sex & Diagnosis & Pretreatment* & $\mathrm{dI}_{\mathrm{Ca}^{*}}{ }^{*}$ \\
\hline & & & & $p A / p F$ \\
\hline 930804 & $81 / \mathrm{M}$ & Coronary artery disease & NO-donor, ${ }^{\S} \mathrm{Ca}$-antagonist & $5.4 \pm 2.4(2)$ \\
\hline 930805 & $16 / \mathrm{F}$ & Ventricular septal defect & Digitalis, amiodarone & $5.5(1)$ \\
\hline 930817 & $62 / \mathrm{M}$ & Coronary artery disease & NO-donor, sotalol & $5.2(1)$ \\
\hline 930818 & $36 / \mathrm{F}$ & Mitral regurgitation & None & $4.2 \pm 2.0(2)$ \\
\hline \multirow[t]{2}{*}{930825} & $65 / \mathrm{M}$ & Coronary artery disease & NO-donor, amiodarone, diuretic & $2.0 \pm 0.6(4)$ \\
\hline & & Mitral regurgitation & & \\
\hline 930831 & $21 / \mathrm{M}$ & Atrial septal defect & None & $3.4 \pm 0.7(3)$ \\
\hline 930901 & $71 / \mathrm{M}$ & Mitral regurgitation & None & $1.3 \pm 0.1(2)$ \\
\hline 930927 & $24 / M$ & Aortic dissection & None & $1.6(1)$ \\
\hline 931014 & $63 / \mathrm{M}$ & Coronary artery disease & NO-donor, Ca-antagonist & $1.3(1)$ \\
\hline 931118 & $67 / M$ & Coronary artery disease & NO-donor, $\beta$-blocker, Ca-antagonist & $3.7 \pm 1.2(3)$ \\
\hline 931202 & $59 / \mathrm{M}$ & Coronary artery disease & Ca-antagonist & $1.9 \pm 0.5(3)$ \\
\hline 921203 & $58 / \mathrm{M}$ & Coronary artery disease & None & $3.4 \pm 1.1(4)$ \\
\hline 931208 & $79 / \mathrm{F}$ & Aortic dissection & None & $1.6 \pm 0.3(3)$ \\
\hline 931213 & $79 / \mathrm{F}$ & Coronary artery disease and aortic stenosis & Amiodarone & $0.8 \pm 0.1(2)$ \\
\hline 931217 & $55 / \mathrm{F}$ & Mitral regurgitation & Amiodarone, diuretic & $0.5(1)$ \\
\hline 931220 & $79 / \mathrm{F}$ & Aortic stenosis & Diuretic & $2.4(1)$ \\
\hline 940214 & $44 / \mathrm{M}$ & Coronary artery disease & ACE-inhibitor, NO-donor, $\beta$-blocker & $1.7 \pm 0.3(2)$ \\
\hline 940215 & $66 / \mathrm{M}$ & Coronary artery disease & NO-donor, diuretic, Ca-antagonist & $2.1 \pm 0.1(2)$ \\
\hline 940302 & $52 / \mathrm{M}$ & Coronary artery disease & $\beta$-blocker, NO-donor & $0.3(1)$ \\
\hline 940303 & $68 / \mathrm{M}$ & Coronary artery disease & Ca-antagonist & $1.4 \pm 0.3(3)$ \\
\hline 940315 & $69 / \mathrm{M}$ & Aortic dissection & None & $8.8(1)$ \\
\hline 940425 & $46 / \mathrm{F}$ & Mitral regurgitation & Digitalis, diuretic & $1.4(1)$ \\
\hline 940502 & $44 / F$ & Mitral regurgitation & Diuretic & $7.8(1)$ \\
\hline 940504 & $60 / \mathrm{F}$ & Coronary artery disease & None & $1.0 \pm 0.1(2)$ \\
\hline 940505 & $22 / \mathrm{M}$ & Atrial septal defect & None & $2.3(1)$ \\
\hline 940509 & $72 / \mathrm{M}$ & Coronary artery disease & Amiodarone & $3.4 \pm 3.1(2)$ \\
\hline 940516 & $51 / \mathrm{M}$ & Aortic stenosis & None & $3.8 \pm 1.5(2)$ \\
\hline 940517 & $58 / \mathrm{F}$ & Mitral stenosis & Ca-antagonist, flecainide & $1.4 \pm 0.1(2)$ \\
\hline 940606 & $16 / \mathrm{F}$ & Ventricular septal defect & None & $3.5 \pm 0.9(4)$ \\
\hline 490706 & $65 / \mathrm{F}$ & Aortic dissection & None & $1.0(1)$ \\
\hline 940713 & 78/M & Aortic stenosis & Diuretic & $2.5 \pm 0.3(2)$ \\
\hline
\end{tabular}

All patients received the same anesthesia: barbiturate, benzodiazepine, curare, antibiotic, morphine, and neuroleptic. * Only drugs with effects on the cardiovascular system are mentioned. ${ }^{\ddagger}$ Density of $\mathrm{I}_{\mathrm{Ca}}$ (mean $\pm \mathrm{SEM}$ with $n$ in parentheses) under basal conditions. ${ }^{8}$ Nitrate and/or molsidomine.

$\mathrm{I}_{\mathrm{Ca}}$ that was slightly larger in this experiment than that produced by milrinone. However, a dual application of SIN-1 and milrinone did not produce a larger effect. The results of a number of similar experiments are shown in Fig. $4 B .100 \mathrm{pM}$ to $1 \mu \mathrm{M}$ SIN-1 produced no effect or a slight inhibition of $\mathrm{I}_{\mathrm{Ca}}$ that was previously stimulated by $10 \mu \mathrm{M}$ milrinone. This suggests that the stimulatory effects of SIN-1 and milrinone were not additive. However, when used at $100 \mu \mathrm{M}, \mathrm{SIN}-1$ significantly reduced the stimulatory effect of milrinone, which may possibly denote the presence of an inhibitory effect of SIN-1 in this range of concentrations.

The effect of SIN-1 and milrinone was further compared by investigating the voltage dependence of their effects on $\mathrm{I}_{\mathrm{Ca}}$. Fig. 5 shows the current-voltage $(A$ and $C)$ and inactivation relationships ( $B$ and $D$ ) obtained in two different experiments. In the first experiment ( $A$ and $B$ ), which is representative of two similar experiments, the effect of $10 \mu \mathrm{M}$ milrinone was examined. In the second experiment $(C$ and $D)$, which is representative of eight similar experiments, we investigated the effect of $1 \mathrm{nM}$ SIN-1. The U-shape of both the current-voltage and inactivation curves of basal $\mathrm{I}_{\mathrm{Ca}}$ as well as their respective positions on the voltage axis are similar to those described by others in human atrial $(46,47)$ and ventricular myocytes $(49,50)$ and are characteristic of the high-threshold L-type calcium current. As shown, milrinone and SIN-1 induced very similar effects on the current-voltage and inactivation curves of $\mathrm{I}_{\mathrm{Ca}}$. Both substances increased $I_{C a}$ at every membrane potential, with a somewhat more pronounced effect at negative potentials. A slight shift of both current-voltage and inactivation curves toward more negative potentials was found with both susbtances. This was also observed with isoprenaline (data not shown and refs. 46,47 ) and suggests that the stimulatory effects of SIN-1, milrinone, and isoprenaline on $\mathrm{I}_{\mathrm{Ca}}$ occur through a common pathway, namely stimulation of cAMP-dependent phosphorylation.

\section{Discussion}

In the present study, we examined the effects of an NO-donor, SIN-1, on the high-threshold calcium current $\left(\mathrm{I}_{\mathrm{Ca}}\right)$ in human 

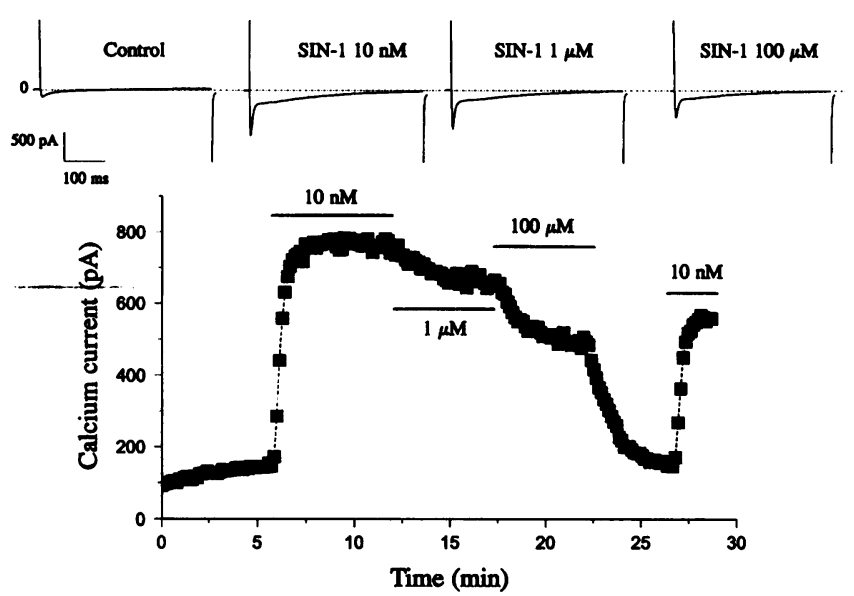

Figure 1. Effects of SIN-1 on $\mathrm{I}_{\mathrm{Ca}}$. (Bottom) Time course of the effects of SIN-1 on basal $\mathrm{I}_{\mathrm{Ca}}$ in an isolated human atrial cardiomyocyte. Each symbol corresponds to a measure of $\mathrm{I}_{\mathrm{Ca}}$ at $\mathrm{O} \mathrm{mV}$, obtained every $8 \mathrm{~s}$ (see Methods). The cell was initially superfused with control Cs Ringer solution. During the periods indicated, the cell was successively exposed to $10 \mathrm{nM}, 1 \mu \mathrm{M}$, and $100 \mu \mathrm{M} \mathrm{SIN-1.} \mathrm{After} \mathrm{washout} \mathrm{of} \mathrm{SIN-1,} \mathrm{the} \mathrm{cell}$ was challenged with a second application of $10 \mathrm{nM}$ SIN-1. (Top) Current traces were obtained from the same experiment under control basal conditions and at the end of the applications of $10 \mathrm{nM}, 1 \mu \mathrm{M}$, and 100 $\mu \mathrm{M}$ SIN-1. The dotted line indicates the zero-current level. The cell was obtained from patient 940517.

atrial myocytes. Several main conclusions can be drawn from our experiments: (a) SIN-1 produces a stimulation of basal $\mathrm{I}_{\mathrm{Ca}}$; (b) this effect occurs in the nanomolar range of concentrations and is not mimicked by SIN-1C; $(c)$ in about two thirds of the cells, an additional inhibitory effect of SIN-1 developed in the micromolar range of concentrations, which counteracts the effect seen at lower concentrations; $(d)$ the maximal stimulatory effect of SIN-1 on $I_{C a}$ is comparable in amplitude with the maximal effects of isoprenaline; $(e)$ milrinone also stimulates basal $\mathrm{I}_{\mathrm{Ca}}$, demonstrating a significant basal activity of adenylyl cyclase and/or cAMP-dependent protein kinase in human atrial cells; and $(f)$ the stimulatory effects of SIN-1 and milrinone on $\mathrm{I}_{\mathrm{Ca}}$ were comparable in amplitude, in their voltage-dependence, and were not additive. We conclude that SIN-1 stimulates $\mathrm{I}_{\mathrm{Ca}}$ in human atrial myocytes by the liberation of NO and propose that this effect is mediated by cGMP-induced inhibition of the cGI-PDE.

Although the effects of SIN-1 on $\mathrm{I}_{\mathrm{Ca}}$ are in accordance with the release of NO and the subsequent activation of soluble guanylyl cyclase, other additional effects of NO could not be completely discarded. For instance, it has been found recently that NO-donors strongly inhibit glyceraldehyde-3-phosphatedehydrogenase in the heart $(51,52)$. In skeletal muscle, this enzyme has been found to bind to the $\alpha 1$-subunit of the Ltype $\mathrm{Ca}^{2+}$ channel (53). Whether glyceraldehyde-3-phosphatedehydrogenase also binds to cardiac $\mathrm{Ca}^{2+}$ channels and affects their activity is unknown. Other works indicate that NO released by SIN-1 can induce S-nitrosylation of cysteine residues, scavenge tyrosyl residues, and possibly deaminate primary amine residues in proteins (54). Although cardiac $\mathrm{Ca}^{2+}$ channels could be subject to such alterations, SIN-1 modified the current-voltage relationship and the time course of $I_{C a}$ in human cardiac
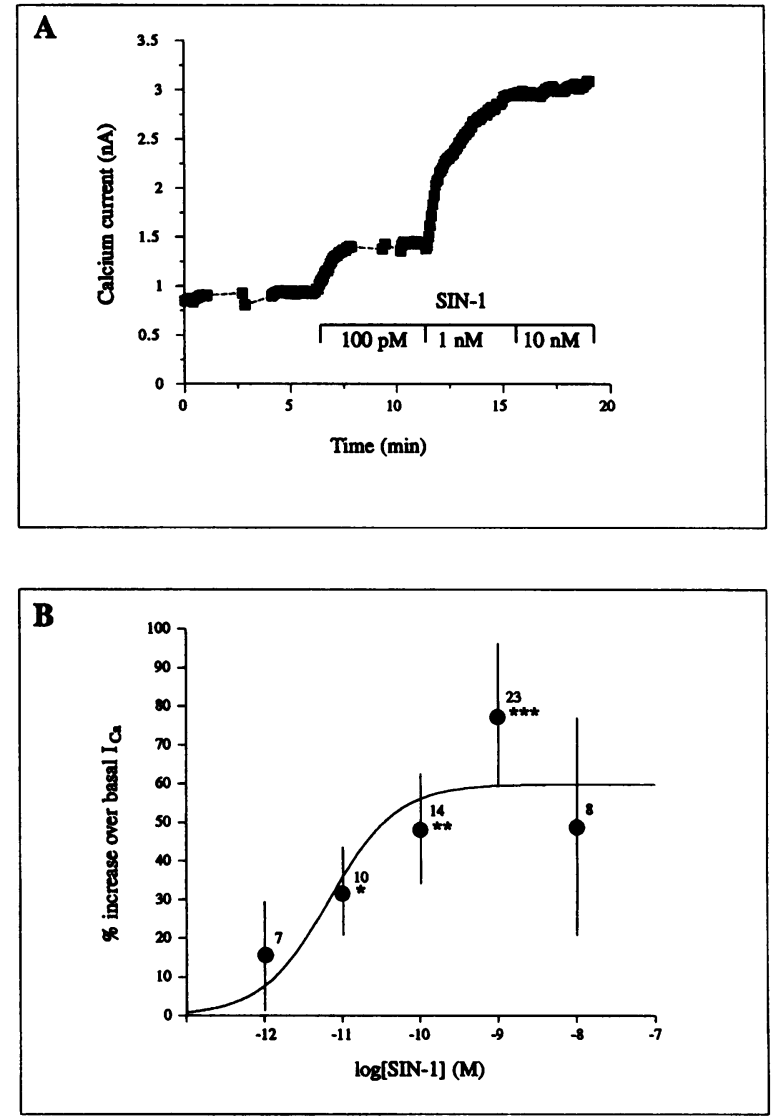

Figure 2. Dose-response of the stimulatory effect of SIN-1 on $\mathrm{I}_{\mathrm{Ca}}$. (A) Time-course of the effects of increasing concentrations of SIN-1 on basal $\mathrm{I}_{\mathrm{C}}$. A human atrial myocyte was initially superfused with control Cs Ringer solution. During the periods indicated, the cell was successively exposed to $100 \mathrm{pM}, 1 \mathrm{nM}$, and $10 \mathrm{nM}$ SIN-1. The cell was obtained from patient 930818 . $(B)$ Dose-response curve for the stimulatory effects of SIN-1 on basal $I_{C a}$. The points show the means \pm SEM of the number of experiments indicated near the points. The response to $\mathrm{SIN}-1$ is expressed as the percentage variation of $\mathrm{I}_{\mathrm{Ca}}$ with respect to its basal level. The continuous line was derived from a nonlinear leastmean-squares regression of the means to the Michaelis equation: effect $=E_{\max }[\mathrm{SIN}-1] /\left([\mathrm{SIN}-1]+E C_{50}\right)$. The numerical values derived for $E_{\max }$ and $E C_{50}$ are $59 \%$ and $7 \mathrm{pM}$, respectively. Significant statistical differences from basal $\mathrm{I}_{\mathrm{Ca}}$ are indicated as $* P<0.05,{ }^{*} P<0.005$, and $* * * P<0.0005$.

myocytes in a manner that was not consistent with functional modifications of the $\mathrm{Ca}^{2+}$ channel protein by SIN-1.

The present study follows up on a recent study of the effects of NO on $\mathrm{I}_{\mathrm{Ca}}$ in frog ventricular myocytes (37). Although we have not measured cGMP concentrations or guanylyl cyclase activity in our preparations, both studies suggest that an endogenous cGMP production controls the regulation of cardiac $\mathrm{Ca}^{2+}$ channel activity. Intracellular perfusion with cGMP was shown earlier to modulate cardiac L-type $\mathrm{Ca}^{2+}$ channel activity in various species (29). In frog ventricular myocytes, cGMP and micromolar concentrations of SIN-1 induce a strong inhibition of cAMP-enhanced $\mathrm{I}_{\mathrm{Ca}}$ that is mediated by the activation of the cGS-PDE $(21,22,37)$. On the other hand, the cGI-PDE appeared to be responsible for the stimulatory effect of nanomolar concentrations of SIN-1 on $\mathrm{I}_{\mathrm{Ca}}$ in this preparation (37). This 


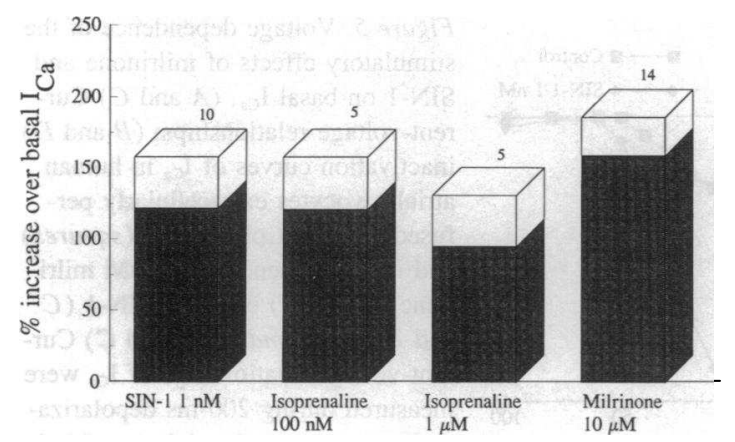

Figure 3. Comparison of the effects of SIN-1, isoprenaline, and milrinone on basal $\mathrm{I}_{\mathrm{Ca}}$. The effects of $1 \mathrm{nM}$ SIN-1, $100 \mathrm{nM}$ and $1 \mu \mathrm{M}$ isoprenaline, and $10 \mu \mathrm{M}$ milrinone on basal $\mathrm{I}_{\mathrm{Ca}}$ are summarized for comparison. Filled and open bars are, respectively, mean values and SEM of the number of experiments indicated near the bars. The responses to the drugs are expressed as the percentage variation of $I_{C a}$ with respect to its basal level. Statistical analysis of the data revealed no significant differences between the data obtained in the different conditions. Note that for the effect of SIN-1, only those cells on which isoprenaline and/or milrinone were also tested are included in this figure.

enzyme is the receptor for bipyridines such as milrinone, amrinone, and so on (48) and is functionally coupled to the $\mathrm{Ca}^{2+}$ channel in frog $(31,32,55)$ and guinea pig ventricular cells $(24,29)$. In both preparations, milrinone was found to exert no effect on basal $\mathrm{I}_{\mathrm{Ca}}$, i.e. in the absence of a previous stimulation of $\mathrm{I}_{\mathrm{Ca}}$ by cAMP-elevating agents. However, after previous stimulation of $\mathrm{I}_{\mathrm{Ca}}$ by isoprenaline, forskolin, or intracellular cAMP, milrinone induces a further increase in $I_{C a}(29,31)$. This suggests that in these preparations, basal cAMP concentration is not high enough to account for a substantial activity of cGIPDE. Here, we found that in human atrial cells milrinone strongly increased $\mathrm{I}_{\mathrm{Ca}}$ at its basal level. Although a number of reasons could account for this discrepancy (species differences, tissue-specificity: atrial vs. ventricular tissue, differences in protocols used for cell dissociation, and so on), it suggests that either more cAMP is present under basal conditions in isolated human atrial myocytes than in isolated frog and guinea pig ventricular cells or cGI-PDE is more efficiently coupled to calcium channels in human atrial myocytes than in other cardiac preparations examined so far. In this respect, it has been found that the intracellular distribution of cGI-PDE in human heart is significantly different from those in the hearts of other animal species (56). In addition to the differences in the effects of milrinone, we found similar differences in the effects of SIN1. Indeed, we found here that SIN-1 also regulates basal $I_{C a}$ in human atrial myocytes, whereas in frog (37) and guinea pig (38) ventricular myocytes, an effect of SIN-1 was only observed after a preliminary stimulation of cAMP-dependent phosphorylation. This strong similarity in the effects of SIN-1 and milrinone may indicate that both compounds act through a common pathway, i.e., inhibition of cGI-PDE. Indeed, in frog ventricular cells, the stimulatory effect of SIN-1 on $I_{C a}$ was absent after a previous application of milrinone (37). Moreover, we found here that milrinone and SIN-1 produced similar maximal effects on $\mathrm{I}_{\mathrm{Ca}}$ amplitude, that both drugs modified the current-voltage and inactivation curves in a manner consistent with an elevation of cAMP-dependent phosphorylation of $\mathrm{Ca}^{2+}$ chan-
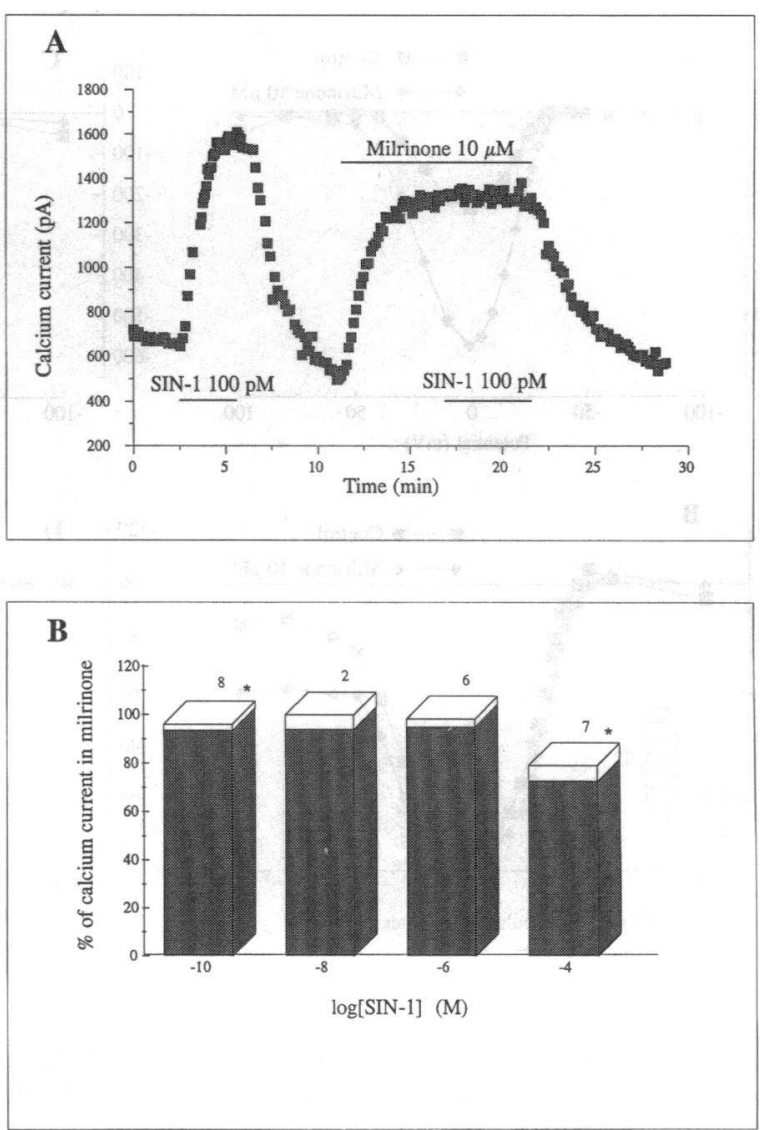

Figure 4. Comparison of the effects of SIN-1 and milrinone on basal $I_{C a}$. (A) A human atrial myocyte was initially superfused with control Cs Ringer solution. During the periods indicated, the cell was superfused with $100 \mathrm{pM}$ SIN-1, $10 \mu \mathrm{M}$ milrinone, and milrinone $+\mathrm{SIN}-1$. The cell was obtained from patient 931118 . (B) Summary of the effects of $100 \mathrm{pM}, 10 \mathrm{nM}, 1$ and $100 \mu \mathrm{M} \mathrm{SIN-1}$ on milrinone $(10 \mu \mathrm{M})$-stimulated $\mathrm{I}_{\mathrm{Ca}}$. Filled and open bars are, respectively, mean values and SEM of the number of experiments indicated near the bars. The response to SIN-1 is expressed as the percentage $\mathrm{I}_{\mathrm{Ca}}$ with respect to its level in milrinone alone. Significant statistical differences from the $\mathrm{I}_{\mathrm{Ca}}$ in milrinone alone are indicated as $* P<0.05$.

nels, and that the effects of milrinone and SIN-1 were not additive. Therefore, our data support the hypothesis that SIN-1 activates human cardiac $\mathrm{Ca}^{2+}$ channels through the inhibition of cGI-PDE. The complete sequence of events would include seven successive steps: $(a)$ liberation of NO from SIN-1, $(b)$ activation by NO of soluble guanylyl cyclase, $(c)$ accumulation of cGMP, $(d)$ cGMP induced inhibition of cGI-PDE, $(e)$ accumulation of cAMP, $(f)$ increase in cAMP-dependent phosphorylation, and $(g)$ stimulation of $\mathrm{I}_{\mathrm{Ca}}$. It should be mentioned, however, that $\mathrm{SIN}-1$ could possibly stimulate basal $\mathrm{I}_{\mathrm{Ca}}$ via an alternate route, namely an activation of cGMP-dependent protein kinase. Although in rat (25), guinea pig (24), and chicken ventricular cells $(26,27)$ this mechanism rather leads to an inhibition of $\mathrm{I}_{\mathrm{Ca}}$, a recent study performed in rabbit ventricular cells demonstrated that it might account for a stimulatory effect of cGMP on basal $\mathrm{I}_{\mathrm{Ca}}(30)$.

In two thirds of the cells, the stimulatory effect of SIN-1 on $\mathrm{I}_{\mathrm{Ca}}$ was reduced when the concentration was increased in 

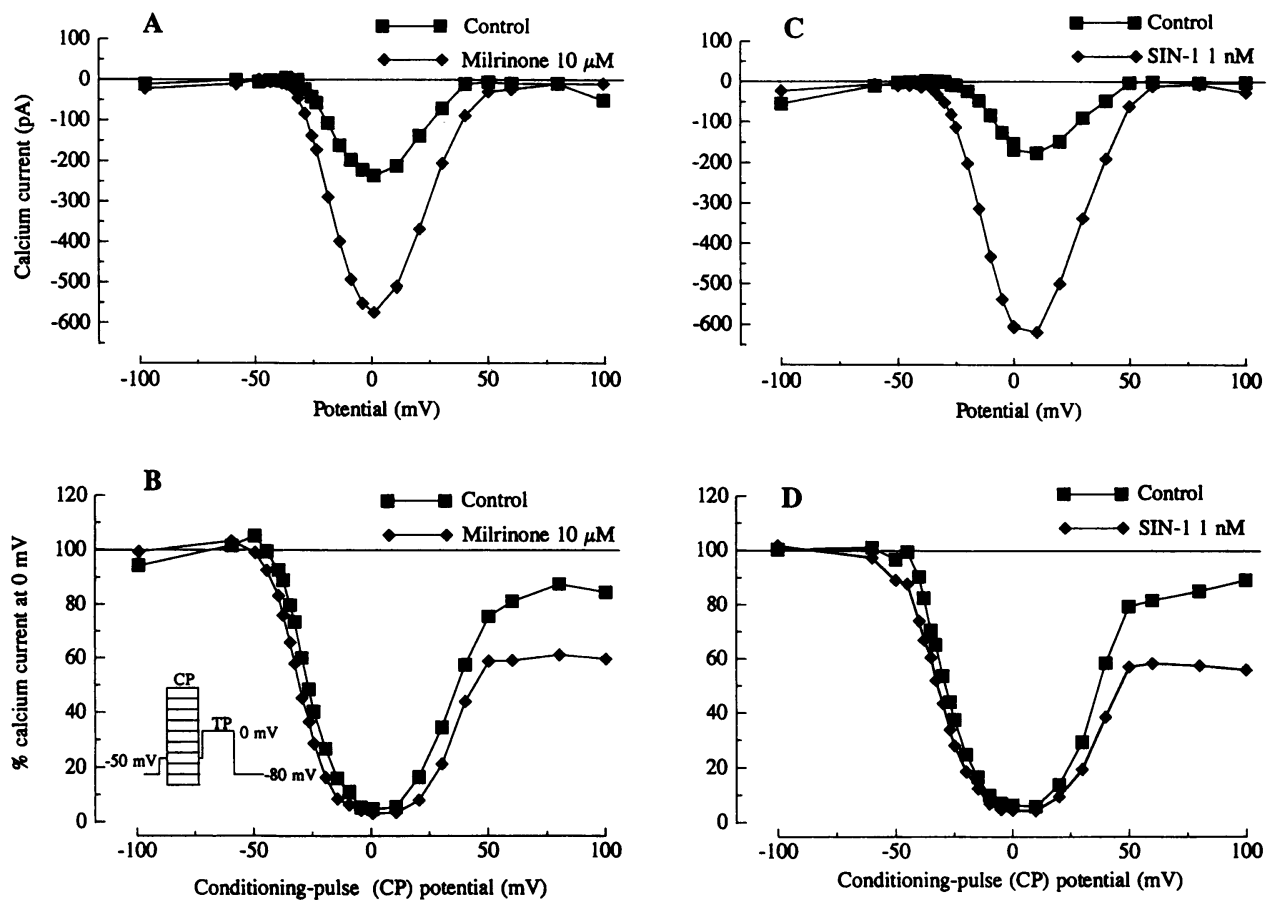

Figure 5. Voltage dependence of the stimulatory effects of milrinone and SIN-1 on basal $\mathrm{I}_{\mathrm{Ca}}$. $(A$ and $C$ ) Current-voltage relationships; ( $B$ and $D$ ) inactivation curves of $\mathrm{I}_{\mathrm{Ca}}$ in human atrial myocytes extracellularly perfused with control solution (squares) and in the presence of $10 \mu \mathrm{M}$ milrinone $(A$ and $B$ ) or $1 \mathrm{nM} \mathrm{SIN-1} \mathrm{(} C$ and $D$ ) (diamonds). ( $A$ and $C$ ) Current-voltage relationships of $\mathrm{I}_{\mathrm{Ca}}$ were measured during 200-ms depolarizations to various potentials (see Methods). ( $B$ and $D$ ) Inactivation curves of $\mathrm{I}_{\mathrm{Ca}}$ were obtained using a doublestep protocol consisting of a $200-\mathrm{ms}$ duration conditioning pulse to various potentials followed by a 200 -ms test potential to $0 \mathrm{mV}$ as indicated in the inset of $B$. $\mathrm{I}_{\mathrm{Ca}}$ measured during a 200ms test pulse at $0 \mathrm{mV}$ is plotted as a function of conditioning pulse potential and expressed as a percentage of $\mathrm{I}_{\mathrm{Ca}}$ at $0 \mathrm{mV}$ in the absence of conditioning pulse. The cells were obtained from patient 930831 ( $A$ and $B$ ) and 930927 ( $C$ and $D$ ). the micromolar range of concentrations. Although a number of possibilities could account for this additional effect of SIN-1, including the nonspecific or indirect effects of NO discussed above, further work is needed to understand the mechanisms involved and what determines the cell-to-cell variability.

The regulation of cardiac $\mathrm{I}_{\mathrm{Ca}}$ by NO-donors may have physiological relevance. Indeed, NO, which is an endothelium-derived relaxing factor (EDRF) (57), can also be synthetized by endocardial (58) and intrinsic neuronal cardiac cells $(59,60)$. In addition, NO released by the endothelial cells of the intracoronary microvasculature is likely to diffuse to the neighboring cardiac myocytes (61). Thus, both in periphery of the heart and in the most inner mass of the muscle $(62)$, there is the physical possibility for released EDRF-NO to reach the cardiomyocytes. It is worth noting that removal of the cardiac endothelium (63) or endocardium (64) has profound effects on cardiac muscle contractility, associated in part with the irreversible failure of some neurotransmitters to enhance cGMP levels (64). Therefore it is likely that EDRF-NO modulates the activity of cardiac muscle under physiological conditions. Besides, neurotransmitters that are responsible for a stimulation of the production of EDRF-NO in the heart (e.g., acetylcholine: refs. 65, 66) are likely to affect cardiac contractility via this pathway. Finally, NO production and NO-synthase activation may play a role in certain pathological conditions. Indeed, endotoxins can induce the expression of the $\mathrm{Ca}^{2+}$-independent inducible NO-synthase in cardiac myocytes $(49,67,68)$ and cytokines accumulation was shown to decrease cardiac contractility through the stimulation of a NO-synthase activity in the cardiomyocytes themselves $(70,71)$. This raises the interesting possibility that, depending on the state of the tissue, NO can serve as a short distance bidirectional messenger between nonmyocytes and myocytes.

SIN-1 is a metabolic product of molsidomine, which is used in the treatment of several cardiovascular disorders (45). A number of studies have showed that SIN-1 relaxes arteries by mimicking the endothelium-dependent relaxation of smooth muscle cells. A therapeutical treatment with molsidomine yields circulating levels of SIN-1 that can be estimated to vary from 1 to $100 \mathrm{nM}$ (72). The present study suggests that in this range of concentration SIN-1 is already high enough to stimulate $\mathrm{I}_{\mathrm{Ca}}$ and may increase atrial contractility in humans.

\section{Acknowledgments}

We thank Mr. Patrick Lechêne and Mrs. Catherine Rücker for skillful technical assistance; Drs. Pierre-Francois Méry and Leif Hove-Madsen for helpful discussions; and Drs. Thierry Folliguet, Patrice Dervanian, Jean-Yves Neveux, and Loïc Macé (Service de Chirurgie Cardiaque, Hôpital Marie Lannelongue, Le Plessis-Robinson, France) for their assistance in obtaining the tissues used in these experiments.

This work was supported by the Association Francaise contre les Myopathies, the Glaxo Laboratories (France), the Hoechst Laboratories (France), the Fédération Francaise de Cardiologie, the Fondation pour la Recherche Médicale, INSERM (CRE 930410), and the French/German PROCOPE exchange program.

\section{References}

1. Hartzell, H. C. 1988. Regulation of cardiac ion channels by catecholamines, acetylcholine and $2^{\text {nd }}$ messenger systems. Prog. Biophys. Mol. Biol. 52:165-247.

2. McDonald, T. F., S. Pelzer, W. Trautwein, and D. J. Pelzer. 1994. Regulation and modulation of calcium channels in cardiac, skeletal, and smooth muscle cells. Physiol. Rev. 74:365-507.

3. Tsien, R. W., B. P. Bean, P. Hess, J. B. Lansman, B. Nilius, and M. Nowycky. 1986. Mechanisms of calcium channel modulation by $\beta$-adrenergic agents and dihydropyridine calcium agonists. J. Mol. Cell. Cardiol. 18:691-710.

4. Trautwein, W., and G. Trube. 1976. Negative inotropic effect of cyclic GMP in cardiac fiber fragments. Pfluegers Arch. 366:293-295.

5. Wilkerson, R. D., R. J. Paddock, and W. J. George. 1976. Effects of derivatives of cyclic AMP and cyclic GMP on contraction force of cat papillary muscles. Eur. J. Pharmacol. 36:247-251. 
6. Nawrath, H. 1977. Does cyclic GMP mediate the negative inotropic effect of acetylcholine in the heart? Nature (Lond.). 267:72-74.

7. Diamond, J., R. E. Ten Eick, and A. J. Trapani. 1977. Are increases in cyclic GMP levels responsible for the negative inotropic effects of acetylcholine in heart? Biochem. Biophys. Res. Commun. 79:912-917.

8. Tuganowski, W., and P. Kopec. 1978. The effect of cGMP in rabbit auricle as studied by a cut-end method. Naunyn-Schmiedebergs Arch. Pharmakol. 304:211-213.

9. Singh, J., and F. W. Flitney. 1981. Inotropic responses of the frog ventricle to dibutyryl cyclic AMP and 8-bromo-cyclic GMP and related changes in endogenous cyclic nucleotide levels. Biochem. Pharmacol. 30:1475-1481.

10. Golberg, N. D., and M. K. Haddox. 1977. Cyclic GMP metabolism and involvement in biological regulation. Annu. Rev. Biochem. 46:823-896.

11. Walter, U. 1984. Cyclic GMP-regulated enzymes and their possible physiological functions. Adv. Cycl. Nucl. Prot. Phosph. Res. 17:249-258.

12. Walter, U. 1989. Physiological role of cGMP and cGMP-dependent protein kinase in the cardiovascular system. Rev. Physiol. Biochem. Pharmacol. 113:4288.

13. Shah, A. M., M. J. Lewis, and A. H. Henderson. 1991. Effects of 8bromo-cyclic GMP on contraction and on inotropic response of ferret cardiac muscle. J. Mol. Cell. Cardiol. 23:55-64.

14. Trautwein, W., J. Taniguchi, and A. Noma. 1982. The effect of intracellular cyclic nucleotides and calcium on the action potential and acetylcholine response of isolated cardiac cells. Pfluegers Arch. 392:307-314.

15. Kohlhardt, M., and K. Haap. 1978. 8-Bromo-guanosine 3',5'-monophosphate mimics the effect of acetylcholine on slow response action potential and contractile force in mammalian atrial myocardium. J. Mol. Cell. Cardiol. 10:573586.

16. Wahler, G. M., and N. Sperelakis. 1985. Intracellular injection of cyclic GMP depresses cardiac slow action potentials. J. Cyclic Nucleotide Protein Phosphorylation Res. 10:83-95.

17. Bkaily, G., and N. Sperelakis. 1985 . Injection of guanosine $3^{\prime}, 5^{\prime}$-cyclic monophosphate into heart cells blocks calcium slow channels. Am. J. Physiol. 248:H745-H749.

18. Mehegan, J. P., W. W. Muir, D. V. Unverferth, R. H. Fertel, and S. M McGuirk. 1985. Electrophysiological effects of cyclic GMP on canine cardiac Purkinje fibers. J. Cardiovasc. Pharmacol. 7:30-35.

19. Nargeot, J., J. M. Nerbonne, J. Engels, and H. A. Lester. 1983. Time course of the increase in the myocardial slow inward current after a photochemically generated concentration jump of intracellular cAMP. Proc. Natl. Acad. Sci. USA. 80:2395-2399.

20. Richard, S., J. M. Nerbonne, J. Nargeot, and H. A. Lester. 1985. Photochemically produced intracellular concentration jumps of cAMP mimic the effects of catecholamines on excitation-contraction coupling in frog atrial fibers. Pfluegers Arch. 403:312-317.

21. Hartzell, H. C., and R. Fischmeister. 1986. Opposite effects of cyclic GMP and cyclic AMP on $\mathrm{Ca}^{2+}$ current in single heart cells. Nature (Lond.). 323:273275.

22. Fischmeister, R., and H. C. Hartzell. 1987. Cyclic guanosine $3^{\prime}, 5^{\prime}$-monophosphate regulates the calcium current in single cells from frog ventricle. $J$. Physiol. Lond. 387:453-472.

23. Levi, R. C., G. Alloatti, and R. Fischmeister. 1989. Cyclic GMP regulates the Ca-channel current in guinea pig ventricular myocytes. Pfluegers Arch. 413:685-687.

24. Ono, K., and W. Trautwein. 1991. Potentiation by cyclic GMP of $\beta$ adrenergic effect on calcium current in guinea-pig ventricular cells. J. Physiol. Lond. 443:387-404.

25. Méry, P.-F., S. M. Lohmann, U. Walter, and R. Fischmeister. 1991. Ca ${ }^{2+}$ current is regulated by cyclic GMP-dependent protein kinase in mammalian cardiac myocytes. Proc. Natl. Acad. Sci. USA. 88:1197-1201.

26. Wahler, G. M., N. J. Rusch, and N. Sperelakis. 1990. 8-Bromo-cyclic GMP inhibits the calcium channel current in embryonic chick ventricular myocytes. Can. J. Physiol. Pharmacol. 68:531-534.

27. Tohse, N., and N. Sperelakis. 1991. cGMP inhibits the activity of single calcium channels in embryonic chick heart cells. Circ. Res. 69:325-331.

28. Bkaily, G., N. Perron, S. Wang, A. Sculptoreanu, D. Jacques, and D. Menard. 1993. Atrial natriuretic factor blocks the high-threshold $\mathrm{Ca}^{2+}$ current and increases $\mathrm{K}^{+}$current in fetal single ventricular cells. J. Mol. Cell. Cardiol. 25:1305-1316

29. Lohmann, S. M., R. Fischmeister, and U. Walter. 1991. Signal transduction by cGMP in heart. Basic Res. Cardiol. 86:503-514.

30. Han, J., C. Leem, C. Ahn, I. So, E. Kim, W. Ho, and Y. E. Earm. 1993. Effect of cyclic GMP on the calcium current in rabbit ventricular myocytes. Korean J. Physiol. 27:151-162.

31. Fischmeister, R., and H. C. Hartzell. 1990. Regulation of calcium current by low- $\mathrm{K}_{\mathrm{m}}$ cyclic AMP phosphodiesterases in cardiac cells. Mol. Pharmacol. 38:426-433.
32. Fischmeister, R., and H. C. Hartzell. 1991. Cyclic AMP phosphodiesterases and $\mathrm{Ca}^{2+}$ current regulation in cardiac cells. Life Sci. 48:2365-2376.

33. Kelm, M., and J. Shrader. 1988. Nitric oxide release from the isolated guinea-pig heart. Eur. J. Pharmacol. 155:317-321.

34. Ishibashi, T., M. Hamaguchi, K. Kato, T. Kawada, H. Ohta, H. Sasage, and S. Imai. 1993. Relationship between myoglobin contents and increases in cyclic GMP produced by glycerol trinitrate and nitric oxide in rabbit aorta, righ atrium and papillary muscle. Naunyn-Schmiedebergs Arch. Pharmacol. 347:553561.

35. Feelisch, M. 1991. The biochemical pathways of nitric oxide formation from nitrovasodilators: appropriate choice of exogenous NO donors and aspects of preparation and handling of aqueous NO solutions. J. Cardiovasc. Pharmacol. 17(Suppl. 3):S25-S33.

36. Cramb, G., R. Banks, E. L. Rugg, and J. F. Aiton. 1987. Actions of atrial natriuretic peptide (ANP) on cyclic nucleotide concentrations and phosphotidylinositol turnover in ventricular myocytes. Biochem. Biophys. Res. Commun. 148:962-970.

37. Méry, P.-F., C. Pavoine, L. Belhassen, F. Pecker, and R. Fischmeister. 1993. Nitric oxide regulates cardiac $\mathrm{Ca}^{2+}$ current-involvement of cGMP-inhibited and cGMP-stimulated phosphodiesterases through guanylyl cyclase activation. J. Biol. Chem. 268:26286-26295.

38. Dollinger, S. J., R. T. Pyo, and G. M. Wahler. 1993. The nitric oxide donor SIN-1 has both stimulatory and inhibitory effects on the cardiac calcium current. J. Mol. Cell. Cardiol. 25(Suppl. III):S14(30). (Abstr.)

39. Legrand, B., E. Deroubaix, J.-P. Couetil, and E. Coraboeuf. 1992. Effects of atrionatriuretic factor on $\mathrm{Ca}^{2+}$ current and $\mathrm{Ca}(\mathrm{i})$-independent transient outward $\mathrm{K}^{+}$current in human atrial cells. Pfluegers Arch. 421:486-491

40. Escande, D., A. Coulombe, J.-F. Faivre, and E. Coraboeuf. 1987. Two types of transient outward currents in adult human atrial cells. Am. J. Physiol. 252:H142-H148.

41. Irisawa, H. 1984. Electrophysiology of single cardiac cells. Jpn. J. Physiol. 34:375-388.

42. Fischmeister, R., and H. C. Hartzell. 1986. Mechanism of action of acetylcholine on calcium current in single cells from frog ventricle. J. Physiol. Lond. 376:183-202.

43. Argibay, J. A., R. Fischmeister, and H. C. Hartzell. 1988. Inactivation, reactivation and pacing dependence of calcium current in frog cardiocytes: correlation with current density. J. Physiol. Lond. 401:201-226.

44. Hartzell, H. C., and R. Fischmeister. 1992. Direct regulation of cardiac $\mathrm{Ca}^{2+}$ channels by G-proteins - neither proven nor necessary? Trends Pharmacol. Sci. 13:380-385.

45. Reden, J. 1990. Molsidomine. Blood Vessels. 27:282-294.

46. Ouadid, H., J. Seguin, S. Richard, P. A. Chaptal, and J. Nargeot. 1991 Properties and modulation of $\mathrm{Ca}$ channels in adult human atrial cells. J. $\mathrm{Mol}$. Cell. Cardiol. 23:41-54.

47. Legrand, B., S. Hatem, E. Deroubaix, J. P. Couetil, and E. Coraboeuf 1991. Calcium current depression in isolated human atrial myocytes after cessation of chronic treatment with calcium antagonists. Circ. Res. 69:292-300.

48. Nicholson, C. D., R. A. J. Challis, and M. Shahid. 1991. Differential modulation of tissue function and therapeutic potential of selective inhibitors of cyclic nucleotide phosphodiesterase isoenzymes. Trends Pharmacol. Sci. 12:19_ 27.

49. Bénitah, J. P., P. Bailly, M. C. Dagrosa, J. P. Daponte, C. Delgado, and P. Lorente. 1992. Slow inward current in single cells isolated from adult human ventricles. Pfluegers Arch. 421:176-187.

50.Beuckelmann, D. J., M. Nabauer, and E. Erdmann. 1991. Characteristics of calcium-current in isolated human ventricular myocytes from patients with terminal heart failure. J. Mol. Cell. Cardiol. 23:929-937.

51. McDonald, L. J., and J. Moss. 1993. Stimulation by nitric oxide of an NAD linkage to glyceraldehyde-3-phosphate dehydrogenase. Proc. Natl. Acad. Sci. USA. 90:6238-6241.

52. Snyder, S. H. 1992. Nitric oxide - 1st in a new class of neurotransmitters Science (Wash. DC). 257:494-496.

53. Kim, K. C., A. H. Caswell, J. A. Talvenheimo, and N. R. Brandt. 1990 Isolation of a terminal cisterna protein which may link the dihydropyridine receptor to the junctional foot protein in skeletal muscle. Biochemistry. 29:9281-9289.

54. Stamler, J. S., D. J. Singel, and J. Loscalzo. 1992. Biochemistry of nitric oxide and its redox-activated forms. Science (Wash. DC). 258:1898-1902.

55. Méry, P.-F., V. Brechler, C. Pavoine, F. Pecker, and R. Fischmeister. 1990. Glucagon stimulates the cardiac $\mathrm{Ca}^{2+}$ current by activation of adenyly cyclase and inhibition of phosphodiesterase. Nature (Lond.). 345:158-161.

56. Masuoka, H., M. Ito, T. Nakano, M. Naka, and T. Tanaka. 1990. Effects of amrinone and enoximone on the subclasses of cyclic AMP phosphodiesterase from human heart and kidney. J. Cardiovasc. Pharmacol. 15:302-307.

57. Furchgott, R. F. 1993. The discovery of endothelium-dependent relaxation Circulation. 87(Suppl. V):V3-V8.

58. Schulz, R., J. A. Smith, M. J. Lewis, and S. Moncada. 1991. Nitric oxide synthase in cultured endocardial cells of the pig. Br. J. Pharmacol. 104:21-24. 
59. Klimaschewski, L., W. Kummer, B. Mayer, J. Y. Couraud, U. Preissler, B. Philippin, and C. Heym. 1992. Nitric oxide synthase in cardiac nerve fibers and neurons of rat and guinea-pig heart. Circ. Res. 71:1533-1537.

60. Schmidt, H. H. H. W., G. D. Gagne, M. Nakane, J. S. Pollock, M. F. Miller, and F. Murad. 1992. Mapping of neural nitric oxide synthase in the rat suggests frequent co-localization with NADPH diaphorase but not with soluble guanylyl cyclase, and novel paraneural functions for nitrinergic signal transduction. J. Histochem. Cytochem. 40:1439-1456.

61. Brutsaert, D. L. 1993. Endocardial and coronary endothelial control of cardiac performance. News Physiol. Sci. 8:82-86.

62. Weber, K. T. 1991. Cardiac intestitium: extracellular space of the myocardium. In The Heart and Cardiovascular System. H. A. Fozzard, E. Haber, R. B. Jennings, A. M. Katz, and H. E. Morgan, editors. Raven Press, New York. 14651480.

63. Ramaciotti, C., A. Sharkey, G. McClellan, and S. Winegrad. 1992. Endothelial cells regulate cardiac contractility. Proc. Natl. Acad. Sci. USA. 89:40334036.

64. Smith, J. A., A. M. Shah, S. Fort, and M. J. Lewis. 1992. The influence of endocardial endothelium on myocardial contraction. Trends Pharmacol. Sci. 13:113-116.

65. Lamontagne, D., U. Pohl, and R. Busse. 1991. NG-nitro-L-arginine antagonizes endothelium-dependent dilator responses by inhibiting endothelium-derived relaxing factor release in the isolated rabbit heart. Pfluegers Ach. 418:266-270.
66. Balligand, J.-L., R. A. Kelly, P. A. Marsden, T. W. Smith, and T. Michel. 1993. Control of cardiac muscle cell function by an endogenous nitric oxide signaling system. Proc. Natl. Acad. Sci. USA. 90:347-351.

67. Salter, M., R. G. Knowles, and S. Moncada. 1991. Widespread tissue distribution, species distribution and changes in activity of Ca-dependent and Caindependent nitric oxide synthases. FEBS (Fed. Eur. Biochem. Soc.) Lett. 291:145-149.

68. Schulz, R., E. Nava, and S. Moncada. 1992. Induction and potential biological relevance of $\mathrm{a} \mathrm{Ca}^{2+}$-independent nitric oxide synthase in the myocardium. Br. J. Pharmacol. 105:575-580.

69. Debelder, A. J., M. W. Radomski, H. J. F. Why, P. J. Richardson, C. A Bucknall, E. Salas, J. F. Martin, and S. Moncada. 1993. Nitric oxide synthase activities in human myocardium. Lancet. 341:84-85.

70. Finkel, M. S., C. V. Oddis, T. D. Jacob, S. C. Watkins, B. G. Hattler, and R. L. Simmons. 1992. Negative inotropic effects of cytokines on the heart mediated by nitric oxide. Science (Wash. DC). 257:387-389.

71. Balligand, J.-L. D. Ungureanu, R. A. Kelly, L. Kobzik, D. Pimental, T. Michel, and T. W. Smith. 1993. Abnormal contractile function due to induction of nitric oxide synthesis in rat cardiac myocytes follows exposure to activated macrophage-conditioned medium. J. Clin. Invest. 91:2314-2319.

72. Fach, W. A., and H. J. Becker. 1984. Wirkdauer und Dosis-WirkungsBeziehung von Molsidomin bei Patienten mit koronarer Herzkrankheit. Z. Kardiol. 73:613-622 